\title{
Nuclear DNA variability within Pisum sativum (Leguminosae): nucleotypic effects on plant growth
}

\author{
A. CAVALLINI, L. NATALI, G. CIONINI* \& D. GENNAI \\ Department of Agricultural Plant Biology of the University, Genetics Section and *Institute of Mutagenesis and \\ Differentiation, C.N.R., Pisa, Italy
}

\begin{abstract}
Nuclear DNA content variability was established among seven cultivars of experimental lines of pea (Pisum sativum L.) by means of Feulgen cytophotometry. In order to study the phenotypic effects of such DNA content variation, different parameters were tested. A positive correlation with root and stem growth was determined during the first developmental stages after germination. In particular, differential response in plant growth seemed to be correlated with differences in enlargement of cells preexisting in the embryo, while no difference was observed in mitotic activity. The results are discussed in relation to the effects of nucleotype on cell and plant growth.
\end{abstract}

Keywords: cell enlargement, cytophotometry, nucleotype, Pisum sativum, plant growth, quantitative DNA variations.

\section{Introduction}

Quantitative nuclear DNA intraspecific variation has been described in a number of species, such as Linum usitatissimum, Microseris douglasii, M. bigelovii, Zea mays, Helianthus annuus and others (see Cavallini \& Natali, 1991). Changes in nuclear DNA content, excluding chromosome endoreduplication and polyploidization, may affect the relative proportions of DNA families in the genome. Although amplification or loss of DNA usually occurs in the repetitive fractions of the genome (see Cullis, 1990), in most cases the sequences involved in variation and their functional significance are not known. It is possible that the total DNA content affects the phenotype through its mere bulk; the nucleotype concept (Bennett, 1972) considers that the DNA content has a developmental and adaptive importance via its effects on parameters such as nuclear volume, cell volume, and mitotic and meiotic cycle time (Price, 1988). In complex multicellular vascular plants, nucleotypic effects may be additive at subsequent cell cycles, so affecting many characters such as growth rate and habit, and generation time (Bennett, 1985; 1987).

Correspondence: Dr Andrea Cavallini, Dipartimento di Biologia delle Piante Agrarie, Sezione di Genetica, Via Matteotti $1 / B$, I-56124 Pisa, Italy.
Following this hypothesis, nucleotypic effects should be very important in ecological adaptation of plants, with significant correlations between low DNA contents and adaptation to stressful environments (Cavallini \& Natali, 1991, and references therein). However, a direct correlation between quantitative DNA variation and growth rate has not yet been fully established.

In a previous paper, wide variation in $4 \mathrm{C}$ nuclear DNA content was shown by means of cytophotometric analyses after Feulgen staining in many cultivars and lines of Pisum sativum (Leguminosae) (Cavallini \& Natali, 1990). Differences in nuclear DNA content were demonstrated both on ethanol-acetic acid and formalin fixed tissues and were related to different chromatin fractions (both eu- and heterochromatic) for different cultivars.

In an attempt to test the nucleotype hypothesis we have studied the correlation of some phenotypic parameters with nuclear DNA content intraspecific variation in pea: this paper describes the results of this study.

\section{Materials and methods}

Seven cultivars or experimental lines of Pisum sativum were kindly supplied by Centro di Miglioramento Genetico delle Piante Orticole, C.N.R., Portici, and Laboratorio di Analisi delle Sementi, M.A.F., Pisa, 
Italy. Seeds were floated on running tap water for $4 \mathrm{~h}$ and germinated in damp vermiculite in a growth chamber at $25^{\circ} \mathrm{C}$ under fluorescent light $(10,000$ lux $)$ with a photoperiod $16 / 8 \mathrm{~h}$ (light-dark). Germination occurred at the same time and with the same frequency in each cultivar or line. Root (from cotyledonary node to the tip) and stem (from cotyledonary node to the plumula) lengths were measured up to 7 days after germination, then plantlets were transplanted to soil and transferred to a glasshouse under the same light intensity and photoperiod. Stem length was measured until flowering. For each cultivar, or line, 15 plantlets were grown to maturity and measured. Other plants were used to determine fresh and dry weights of root, stem, and cotyledon at different times after germination (five plantlets per cultivar per sampling time).

For other analyses, tissues were collected from seedlings 5 days after germination in damp vermiculite. Shoot tips were fixed in ethanol-acetic acid 3:1 (v:v). Squashes were made under a cover-slip in a drop of $45 \%$ acetic acid, after treatment with a $5 \%$ aqueous solution of pectinase (Sigma) for $30 \mathrm{~min}$ at $37^{\circ} \mathrm{C}$. The cover-slips were removed by the solid $\mathrm{CO}_{2}$ method and the preparations were stained, after a $7 \mathrm{~min}$ hydrolysis time in $1 \mathrm{~N} \mathrm{HCl}$ at $60^{\circ} \mathrm{C}$, in Feulgen reagent containing 0.5 per cent basic fuchsin for $1 \mathrm{~h}$, according to Cavallini \& Natali (1990). After staining, the slides were subjected to three 10 min washes in $\mathrm{SO}_{2}$ water prior to dehydration and mounting in DPX $(\mathrm{BDH})$. Feulgen/DNA absorptions of 50 early prophase nuclei $(=4 \mathrm{C})$ per cultivar were determined at the wavelength of $550 \mathrm{~nm}$ using a Barr \& Stroud GN5-type integrating microdensitometer. Primary root tips were also collected 1 to 4 days after germination and processed as above.

For histology, epicotyls and differentiated roots ( 3 $\mathrm{cm}$ from the tip) were collected from the same plantlets, fixed in 4 per cent formalin overnight and transferred to 70 per cent ethanol. Standard histological techniques were followed to achieve dehydration and material was embedded in paraffin wax. Sections were cut at $20 \mu \mathrm{m}$ with a rotary microtome, stained with Delafield's haematoxylin and mounted in DPX. After microphotographic mapping, the lengths of the cells in the 5-7 outer layers of both roots and epicotyls, previously chosen according to their DNA content, were measured ( 30 cells per five plantlets per cultivar).

Epidermal peels were made from the fourth leaf of 30-day-old plantlets and, after photocopying photographs on Wattman $3 \mathrm{M}$ paper, cell area was determined by cutting and weighing cell shapes (100 cells per cultivar).

Correlation coefficients were established between $4 \mathrm{C}$ nuclear DNA content of the cultivars and the single parameters analysed; their significance was determined using a $t$-test (confidence limits at $0.05>P>0.02[*$, $\left.0.02>P>0.01[* * *], 0.01>P>0.0011^{[* * *]}\right)$.

\section{Results}

4C nuclear DNA contents of seven cultivars and lines of pea were determined by Feulgen cytophotometry and are reported in Table 1 . The results confirm the previous determinations reported by Cavallini \& Natali (1990). In Tables 1-2, root and stem length at different times after germination are also reported, and also the correlation coefficients with nuclear DNA content. Positive correlations were statistically significant at 3 and 5 days of root growth and at 4, 7 and 14 days of stem growth; correlations at 7 days of root growth and 20 days of stem growth were not significant.

Root and epicotyl cell lengths, and leaf epidermal cell areas (Fig. 1), are reported in Table 3. Here also positive correlations coefficients are seen among cultivars for each parameter vs. 4C DNA content. It is worth noting that the root and epicotyl cells chosen for analysis were all in the $G_{2}(4 C)$ period of interphase, while leaf epidermal cells were in the $G_{1}(2 C)$ period (see also Evans \& Van't Hof, 1975), i.e. differences in cell size were not correlated with different ploidy levels of the cells.

No mitotic activity was found in root apices during the first $40 \mathrm{~h}$ after germination in any cultivar tested. Subsequently, similar mitotic indices were found up to 4 days after germination.

No correlations were established between DNA content and fresh or dry weight of cotyledons, stem and roots, seed weight, rate of cotyledon weight diminution or flowering time (data not reported).

\section{Discussion}

The influence of nuclear DNA content on many nuclear, cellular, tissue and organismal phenotypic characters has been studied among different Angiosperm species (see Bennett, 1987, and references therein), but contrasting results have been reported. For examples, a positive correlation between cell growth and nuclear DNA content has been reported among a wide range of species (Price, 1976; Nagl, 1982), but exceptions to this general rule do occur, as in the case of the genus Sisyrinchium (Kenton et al., 1986). For mitotic cycle time, positive correlations to DNA content in diploid plants have been observed in some species (Van't Hof \& Sparrow, 1963), but not in others (Nagl, 1974). A possible explanation for these contrasting results is the genetic diversity occurring 
Table 1 Mean values $( \pm$ S.E. $)$ of $4 \mathrm{C}$ nuclear DNA content (arbitrary units) and primary root length $(\mathrm{mm})$ in 7 cultivars and experimental lines of Pisum sativum after different time periods after germination (for details see text). The correlation coefficients between $4 \mathrm{C}$ DNA content and root length at different times, and their significance, are also reported ${ }^{* * *}: 0.01>P>0.001{ }^{* *}: 0.02>P>0.01$; $*: 0.05>P>0.02)$

\begin{tabular}{|c|c|c|c|c|}
\hline \multirow[b]{2}{*}{ Cultivar } & \multirow{2}{*}{$\begin{array}{l}\text { 4C DNA } \\
\text { content }\end{array}$} & \multicolumn{3}{|c|}{ Primary root length } \\
\hline & & After 3 days & After 5 days & After 7 days \\
\hline $\begin{array}{l}\text { Espresso } \\
\text { Generoso }\end{array}$ & $16.6 \pm 0.2$ & $24.0 \pm 1.1$ & $58.5 \pm 2.4$ & $108.4 \pm 4.2$ \\
\hline $\begin{array}{l}\text { Dolce } \\
\text { Provenza }\end{array}$ & $16.0 \pm 0.1$ & $21.4 \pm 1.0$ & $57.0 \pm 2.7$ & $100.3 \pm 4.6$ \\
\hline Vip & $15.2 \pm 0.1$ & $12.7 \pm 0.5$ & $44.4 \pm 1.4$ & $81.2 \pm 5.2$ \\
\hline Senatore & $14.6 \pm 0.2$ & $11.3 \pm 0.3$ & $36.9 \pm 1.5$ & $68.0 \pm 3.7$ \\
\hline 5075 & $14.4 \pm 0.1$ & $10.4 \pm 0.3$ & $43.3 \pm 1.3$ & $71.5 \pm 4.2$ \\
\hline Telefono & $14.1 \pm 0.1$ & $13.6 \pm 0.5$ & $38.7 \pm 1.0$ & $79.7 \pm 4.0$ \\
\hline $\begin{array}{l}\text { Nano } \\
\text { Progress }\end{array}$ & $13.0 \pm 0.2$ & $8.8 \pm 0.2$ & $37.5 \pm 0.9$ & $80.0 \pm 4.2$ \\
\hline $\begin{array}{l}\text { Correlation } \\
\text { coefficient }\end{array}$ & & $0.90^{* * * *}$ & $0.89^{* * *}$ & 0.75 \\
\hline
\end{tabular}

Table 2 Mean values ( \pm S.E.) of $4 \mathrm{C}$ nuclear DNA content (arbitrary units) and stem length $(\mathrm{mm})$ in 7 cultivars and experimental lines of Pisum sativum after different time periods after germination (for details see text). The correlation coefficients between $4 C$ DNA content and stem length at different times, and their significance, are also reported $\left({ }^{* * *}: 0.01>P>0.001\right.$; $* *: 0.02>P>0.01 ; *: 0.05>P>0.02)$

\begin{tabular}{|c|c|c|c|c|c|c|}
\hline \multirow[b]{2}{*}{ Cultivar } & \multirow{2}{*}{$\begin{array}{l}\text { 4C DNA } \\
\text { content }\end{array}$} & \multicolumn{5}{|l|}{ Stem length } \\
\hline & & After 4 days & After 7 days & After 14 days & After 20 days & After 44 days \\
\hline $\begin{array}{l}\text { Espresso } \\
\text { Generoso }\end{array}$ & $16.6 \pm 0.2$ & $40.3 \pm 2.2$ & $70.7 \pm 3.1$ & $95.0 \pm 3.8$ & $211.6 \pm 6.1$ & $348.0 \pm 22.0$ \\
\hline $\begin{array}{l}\text { Dolce } \\
\text { Provenza }\end{array}$ & $16.0 \pm 0.1$ & $41.3 \pm 2.3$ & $60.7 \pm 2.1$ & $79.0 \pm 2.0$ & $130.2 \pm 4.2$ & $223.8 \pm 14.0$ \\
\hline Vip & $15.2 \pm 0.1$ & $31.7 \pm 1.8$ & $55.0 \pm 2.0$ & $71.5 \pm 1.9$ & $109.0 \pm 3.9$ & $288.2 \pm 18.0$ \\
\hline Senatore & $14.6 \pm 0.2$ & $29.0 \pm 1.7$ & $56.0 \pm 2.0$ & $72.5 \pm 1.9$ & $135.2 \pm 5.2$ & $551.6 \pm 42.5$ \\
\hline 5075 & $14.4 \pm 0.1$ & $28.3 \pm 1.5$ & $53.6 \pm 1.7$ & $75.7 \pm 2.4$ & $163.6 \pm 4.9$ & $744.6 \pm 65.3$ \\
\hline Telefono & $14.1 \pm 0.1$ & $26.4 \pm 1.1$ & $53.0 \pm 1.8$ & $85.4 \pm 3.1$ & $163.8 \pm 4.8$ & $682.2 \pm 41.4$ \\
\hline $\begin{array}{l}\text { Nano } \\
\quad \text { Progress }\end{array}$ & $13.0 \pm 0.2$ & $24.1 \pm 0.9$ & $31.0 \pm 2.0$ & $42.4 \pm 2.0$ & $64.0 \pm 3.5$ & $140.0 \pm 13.2$ \\
\hline $\begin{array}{l}\text { Correlation } \\
\text { coefficient }\end{array}$ & & $0.95^{* * *}$ & $0.93^{* * *}$ & $0.77^{*}$ & 0.64 & 0.15 \\
\hline
\end{tabular}

among species (Karp et al. 1982; Bennett, 1987; Cavallini \& Natali, 1991).

In order to reduce the effects of genetic diversity, we have tested the nucleotype hypothesis among cultivars and experimental lines of one species, Pisum sativum, where a maximum variation of 22.5 per cent of $4 \mathrm{C}$ DNA content has been established (Cavallini \& Natali,
1990; see also Table 1). According to Price (1988), 5-10 per cent variation in nuclear DNA content might be sufficient to become of significance to the organism.

In pea, a positive correlation exists between $4 \mathrm{C}$ nuclear DNA content and growth rate of both root and stem, at least in the first developmental phases (Tables 1-2). The influence of different DNA mass on the 

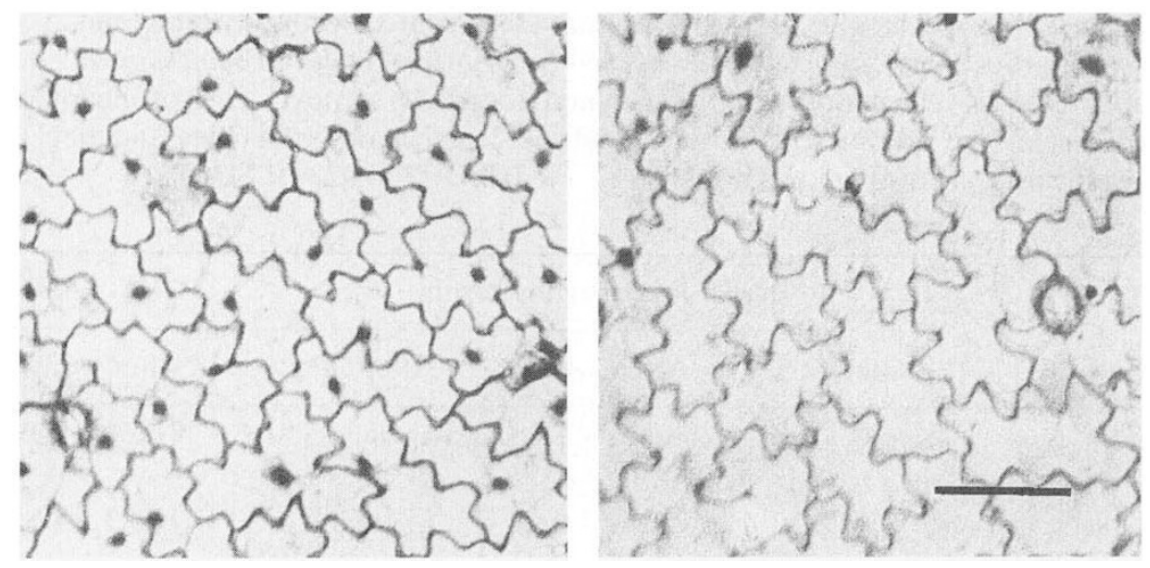

Fig. 1 Epidermal cells of Pisum sativum, cvs, 'Espresso Generoso' (right) and 'Nano Progress' (left). Bar corresponds to $50 \mu \mathrm{m}$. Delafield's haematoxylin.

Table 3 Mean values ( \pm S.E.) of 4 C nuclear DNA content (arbitrary units), differentiated root and epycotyl cell length (a.u.) and leaf epidermal cell area (a.u.) in 7 cultivars and experimental lines of Pisum sativum (for details see text). The correlation coefficients between $4 \mathrm{C}$ DNA content and the different parameters, and their significance, are also reported $\left({ }^{* * *}: 0.01>P>0.001 ; * *: 0.02>P>0.01\right.$; $*: 0.05>P>0.02$ )

\begin{tabular}{lllll}
\hline Cultivar & $\begin{array}{l}\text { 4C DNA } \\
\text { content }\end{array}$ & $\begin{array}{l}\text { Differentiated } \\
\text { root cell length }\end{array}$ & $\begin{array}{l}\text { Epycotyl } \\
\text { cell length }\end{array}$ & $\begin{array}{l}\text { Leaf epidermal } \\
\text { cell area }\end{array}$ \\
\hline $\begin{array}{l}\text { Espresso } \\
\quad \text { Generoso }\end{array}$ & $16.6 \pm 0.2$ & $27.73 \pm 0.31$ & $17.85 \pm 0.18$ & $123.74 \pm 2.31$ \\
$\begin{array}{l}\text { Dolce } \\
\quad \text { Provenza }\end{array}$ & $16.0 \pm 0.1$ & $22.88 \pm 0.29$ & $17.08 \pm 0.09$ & $109.22 \pm 2.12$ \\
$\quad$ Vip & $15.2 \pm 0.1$ & $20.01 \pm 0.19$ & $15.11 \pm 0.15$ & $100.08 \pm 1.93$ \\
Senatore & $14.6 \pm 0.2$ & $21.80 \pm 0.22$ & $16.53 \pm 0.13$ & $106.22 \pm 2.01$ \\
5075 & $14.4 \pm 0.1$ & $20.70 \pm 0.24$ & $12.23 \pm 0.10$ & $100.05 \pm 1.64$ \\
Telefono & $14.1 \pm 0.1$ & $18.82 \pm 0.17$ & $14.28 \pm 0.10$ & $97.01 \pm 1.13$ \\
Nano & $13.0 \pm 0.2$ & $18.75 \pm 0.18$ & $9.37 \pm 0.12$ & $96.36 \pm 1.22$ \\
$\quad$ Progress & & & & \\
Correlation & & $0.86^{* *}$ & $0.89^{* * * *}$ & $0.86^{* *}$ \\
$\quad$ coefficient & & & & \\
\hline
\end{tabular}

development seems to cease after 5 days for the root (Table 1) and 14 days for the stem (Table 2).

According to the nucleotype hypothesis (see the Introduction), growth rate should be affected by nuclear DNA content through its effects on either mitotic cycle time and/or cell volume: high DNA content should induce longer mitotic cycle time but greater cell volume, while low DNA content should be associated with shorter mitotic cycle time and reduced cell volume. Similar behaviour has been observed by Karp et al. (1982) in a triploid Hyacinthus orientalis.

To establish the cellular basis of the different growth rates of pea cultivars during the early developmental stages, we measured cell enlargement in differentiated root and epicotyl tissues and found a positive correlation with nuclear DNA content (Table 3). By contrast, no differences between cultivars were found in the mitotic activity of primary roots. Thus, the higher growth rates observed in pea cultivars with high DNA content appear to be essentially correlated with the presence of larger cells. Nucleotypic effects on growth rate are detectable only in early developmental stages, when growth is mostly attributable to enlargement of pre-existing cells in the embryo. It is conceivable that the effects of nuclear DNA content are then masked by the different genetic backgrounds of the cultivars (for example, 'Dolce Provenza' and 'Nano Progress' are dwarf cultivars, 'Vip' and 'Espresso Generoso' are 
semi-dwarfs). However, some nucleotypic effects may have occurred also in adult plants since leaf epidermal cell areas show a significant positive correlation with nuclear DNA content (Table 3).

Nuclear DNA content might also affect mitotic cycle time in subsequent developmental stages. Further experiments would be necessary to establish cell cycle duration in the shoot apex of adult plants. The effects of nuclear DNA content on cell cycle duration are debatable: species with small nuclear volumes usually show shorter cell cycles (Grime, 1983), but a negative correlation has been reported between DNA content and mitotic cycle time in the roots of cultivars of Helianthus annuus (Olszewska et al., 1984).

Finally, our experiments indicate that quantitative nuclear DNA intraspecific variability may affect the phenotype even when plants are grown under controlled and optimal conditions. This influence may be more effective when growth conditions are limiting. Further studies are necessary using wild plants from contrasting environments.

\section{Acknowledgements}

Research supported by National Research Council of Italy, Special Project RAISA, Sub-project N. 2, Paper N. 345 .

\section{References}

BENNETT, M. D. 1972. Nuclear DNA content and minimum generation time in herbaceous plants. Proc. Royal Soc. Lond., Ser. B, 181, 109-135.

BENNETT, M. D. 1985. Intraspecific variation in DNA amount and the nucleotypic dimension in plant genetics. In: Freeling, M. (ed.) Plant Genetics, A. R. Liss, New York, pp. 283-302.
BENNETT, M. D. 1987. Variation in genomic form in plants and its ecological implications. New Phytol., 106, 177-200.

CAVALlini, A. AND NATALI, L. 1990. Nuclear DNA variability within Pisum sativum (Leguminosae): cytophotometric analyses. Plant Syst. Evol., 173, 179-185.

CAVALLINI, A. AND NATALI, L. 1991. Intraspecific variation of nuclear DNA content in plant species. Caryologia, 44, 93-107.

CULLIS, c. A. 1990. DNA rearrangements in response to environmental stress. Adv. Genet., 28, 73-97.

EVANS, L. S. AND VAN'T HOF, J. 1975. Is polyploidy necessary for tissue differentiation in higher plants? Am. J. Bot., 62, 1060-1064.

GRIME, J. P. 1983. Predictions of weed and crop response to climate based upon measurements of nuclear DNA content. Aspects of Appl. Biol., 4, 87-98.

KARP, A., REES, H. AND JEWELL, A. W. 1982. The effects of nucleotype and genotype upon pollen grain development in Hyacinthus and Scilla. Heredity, 48, 251-261.

KENTON, A. Y., RUDALl, P. J. AND JOHNSON, A. R. 1986. Genome size variation in Sisyrinchium L. (Iridaceae) and its relationship to phenotype and habitat. Bot. Gaz., 147, 342-354.

NAGL, w. 1974. Mitotic cycle time in perennial and annual plants with various amounts of DNA and heterochromatin. Dev. Biol., 39, 342-346.

NAGL, w. 1982. Cell growth and nuclear DNA increase by endoreduplication and differential DNA replication. In: Nicolini, C. (ed.) Cell Growth, Plenum, New York, pp. 619-651.

OLSZEWSKA, M. M. J., MARCINIAK, K., KURAN, H., DAMSZ, B. AND BILECKA, A. 1984. Cytochemical study of cell cycle parameters in two cultivars of Helianthus annuus L. Dry mass increase as a possible factor regulating cell cycle duration. Caryologia, 37, 177-195.

PRICE, H. J. 1976. Evolution of DNA content in higher plants. Bot. Rev., 42, 27-52.

PRICE, H. J. 1988. DNA content variation among higher plants. Ann. Missouri Bot. Gard., 75, 1248-1257.

VAN'T HOF, J. AND SPARROW, A. H. 1963. A relationship between DNA content, nuclear volume, and minimum mitotic cycle time. Proc. Natl. Acad. Sci. U.S.A., 49, 897-902. 